\title{
Acyclic 1,4-Stereocontrol via Reductive 1,3-Transpositions
}

\author{
Wei Qi and Matthias C. McIntosh ${ }^{*}$ \\ 119 Chemistry Bldg, University of Arkansas, Fayetteville, AR 72701
}

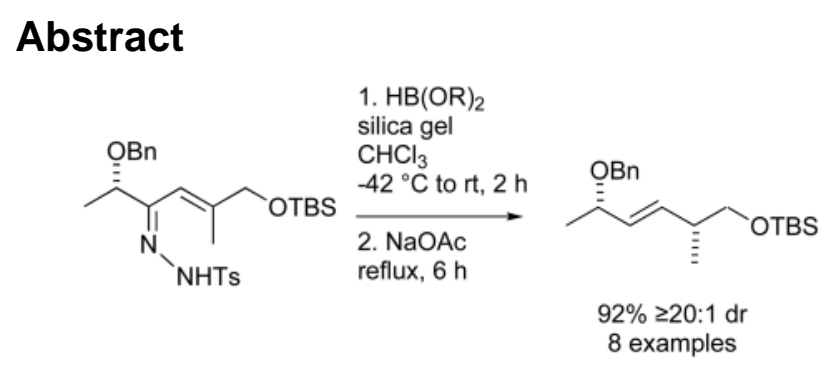

One-pot reduction/allylic diazene rearrangement of lactic and mandelic acid-derived $\alpha, \beta$-unsaturated tosyl hydrazones leads to 1,4-syn- or 1,4-anti-E-2-alkenyl arrays in high yield and diastereoselectivity. Either the syn or the anti diastereomer can be prepared by choosing the appropriate alkene stereoisomer of the hydrazone. The $E$-alkenes led to the 1,4-syn isomers, while the $Z$-alkenes led to the 1,4-anti isomers, both with $\geq 20: 1$ diastereoselectivity.

The allylic diazene rearrangement (ADR) in its simplest form is the retro ene reaction of 1diazo-2-propene to afford molecular nitrogen and propene (Scheme 1$).{ }^{1}$ The ADR is often encountered as the final step in the reductive 1,3-transposition of $\alpha, \beta$-unsaturated tosylhydrazones to the reduced alkenes. ${ }^{2}$ More recently, the ADR has been employed in reductive Mitsunobu reactions, ${ }^{3}$ reductive alkylations, ${ }^{4}$ and in reductive transpositions of Diels-Alder adducts of 1-hydrazino dienes. ${ }^{5,6}$

If the terminal carbon of the alkene of the allylic diazene is prochiral, a stereocenter can be installed via the ADR. Indeed, the ADR has been employed in a variety of cyclic systems to establish sp ${ }^{3}$ stereocenters. ${ }^{2,5,6}$ However, to our knowledge there have been no reports of the use of the reaction to install $\mathrm{sp}^{3}$ stereocenters in acyclic systems.

We envisioned that diastereoselective reduction of an $\alpha, \beta$-unsaturated tosylhydrazone could be achieved under the influence of an $\alpha$-alkoxy stereocenter (Scheme 2). An unsaturated sulfonyl hydrazone containing an alkoxy group at the $\alpha$-stereocenter might participate in either Felkin-Anh or Cram chelation controlled reduction of the hydrazone imine. The suprafacial nature of the rearrangement, coupled with allylic strain induced conformational constraints, $4 a, 7$ should result in diastereoselective transfer of the diazene hydrogen to one face of the prochiral alkene carbon.

Hydroxy and alkyl groups possessing 1,4-syn and/or 1,4-anti relationships are encountered in a variety of biologically significant marine natural products, including amphidinolide $\mathrm{J},{ }^{8}$ reidispongiolide $\mathrm{A},{ }^{9}$ mycoticin, ${ }^{10}$ okadaic acid, ${ }^{11}$ halichlorine, ${ }^{12}$ pinnaic acid ${ }^{13}$ and many

mcintosh@uark.edu.

Supporting Information Available: Experimental procedures, characterization data, ${ }^{1} \mathrm{H}$ - and ${ }^{13} \mathrm{C}$-NMR spectra of compounds $\mathbf{1 a}-\mathbf{h}$ and 2a-h, X-ray crystal structure data of the hydrazone leading to $\mathbf{2 f}$, Mosher ester analyses of 2a,d. This material is available free of charge via the Internet at http://pubs.acs.org. 
others. A diastereoselective acyclic reductive 1,3-transposition would greatly expand the utility of the reaction. We report herein the realization of this transformation in the generation of both 1,4-syn and 1,4-anti constructs.

A necessary first step of the proposed reductive transposition is the diastereoselective reduction of acyclic $\alpha$-alkoxy sulfonyl hydrazones (Scheme 2). Although there was little precedent for this transformation, ${ }^{14}$ we were encouraged by a number of reports of diastereoselective reduction of acyclic $\alpha$-hydroxy or $\alpha$-alkoxy oximes using a variety of reducing agents. ${ }^{15}$

We chose to test the viability of the reductive transposition on lactic and mandelic acid derived substrates (Scheme 2, $\mathrm{R}_{2}=\mathrm{Me}$ or $\mathrm{Ph}$ ). Siloxymethyl, siloxyethyl and ethenyl were chosen as the $\mathrm{R}_{4}$ substituents, since these groups would be useful in post-rearrangement manipulations that might be employed in natural product synthesis.

Thus, tosyl hydrazone 1a was prepared in 4 steps from $(S)$-(+)-lactic acid (Scheme 3). ${ }^{16}$ During optimization studies on the reductive transposition, we found that a modification (addition of 2 weight eq of silica gel) of the Kabalka conditions ${ }^{17}$ greatly accelerated the hydrazone reduction step. After addition of $\mathrm{NaOAc}$ and heating of the reaction mixture, the 1,4-syn-E-2alkenyl product 2a was isolated in high yield and diastereoselectivity $\left(\geq 20: 1 d r\right.$ based on ${ }^{1} \mathrm{H}$ NMR analysis). ${ }^{18}$ Importantly, Mosher ester analysis of a derivative of 2 a revealed that no detectable racemization of the $\alpha$-alkoxy stereocenter had occurred during the entire reaction sequence from (S)-(+)-lactic acid to $2 \boldsymbol{a} .{ }^{16}$

The 1,4-syn adducts $\mathbf{2 b}$ and $\mathbf{2 c}$ were prepared in a directly analogous fashion (Figure 1). Each was isolated in very good yield and uniformly high level of isomeric purity $(d r \geq 20: 1)$. Solely the $E$-alkene isomer was detected by ${ }^{1} \mathrm{H}$-NMR analysis.

The mandelic acid derived hydrazones afforded equally high levels of diastereoselectivity in the reductive transposition to give adducts $\mathbf{2 d - f}$ (Figure 1). The $\mathrm{er}$ of adduct $\mathbf{2 d}$ was identical to that of its Weinreb amide precursor, ${ }^{16,19}$ indicating that no detectable racemization of the alkoxy-bearing stereocenter had occurred in its conversion to $\mathbf{2 d}$.

In order to access the corresponding 1,4-anti diastereomers, tosyl hydrazones $\mathbf{2 g}$ and $\mathbf{2 h}$ possessing Z-alkenes were prepared (Scheme 4). Although the stereoselectivity in the hydrazone formation step was not as high (70:30 and 65:35E:Z, respectively), the $E$-hydrazone isomer could nevertheless be crystallized in isomerically pure form from the mixture.

Gratifyingly, treatment of hydrazones $\mathbf{1 g}$ and $\mathbf{1 h}$ under the same conditions as before yielded the 1,4-anti-E-2-alkenyl diastereomers $\mathbf{2} \mathbf{g}$ and $\mathbf{2 h}$ in good yield and $\geq 20: 1 d r$. As with $\mathbf{2 a - f}$, only the $E$-alkene isomer was detected by ${ }^{1} \mathrm{H}$-NMR analysis.

The reductive transposition described herein has several features that recommend its use: (i) the ready accessibility of the $\alpha$-alkoxy tosylhydrazone precursors; ${ }^{16}$ (ii) the mild reaction conditions for effecting the transformation; and (iii) the ability to prepare either the 1,4-syn or 1,4-anti diastereomers.

This method described herein is complementary to other methods used for acyclic 1,4stereocontrol, such as the Claisen ${ }^{20}$ and 2,3-Wittig ${ }^{21}$ rearrangements, and the $\mathrm{S}_{\mathrm{N}} 2^{\prime}$ reactions of organometals. ${ }^{22}$ Our own applications to complex molecule synthesis will be reported in due course. 


\section{Acknowledgements}

We thank the NSF (CHE-0616154), the NIH (RR-15569) and the Arkansas Biosciences Institute for support of this work, and Gavin D. Jones (Arkansas Tech University) and David A. Vicic (University of Hawaii) for X-ray crystallographic analysis.

\section{References}

1. Bumgardner CL, Freeman JP. J Am Chem Soc 1964;86:2233.Jabbari A, Sorensen EJ, Houk KN. Org Lett 2006;8:3105. [PubMed: 16805563]

2. For representative examples, see: Hutchins RO, Kacher M, Rua L. J Org Chem 1975;40:923.Girotra NN, Wendler NL. Tetrahedron Lett 1982;23:5501.Danheiser RL, Carini DJ, Fink DM, Basak A. Tetrahedron 1983;39:935.Silvestri MG, Bednarski PJ, Kho E. J Org Chem 1985;50:2798.Steinmeyer A, Neef G. Tetrahedron Lett 1992;33:4879.Greco MN, Maryanoff BE. Tetrahedron Lett 1992;33:5009.Tanaka T, Maeda K, Mikamiyama H, Funakoshi Y, Uenaka K, Iwata C. Tetrahedron 1996;52:4257.Fürstner A, Szillat H, Gabor B, Mynott R. J Am Chem Soc 1998;120:8305.Harmata M, Bohnert GJ. Org Lett 2003;5:59. [PubMed: 12509890]Hutchison JM, Lindsay HA, Dormi SS, Jones GD, Vicic DA, McIntosh MC. Org Lett 2006;8:3663. [PubMed: 16898786]Movassaghi M, Ahmad OK. J Org Chem 2007;72:1838-1841. [PubMed: 17274659]For a review, see: Ripoll J-L, Vallée Y. Synthesis 1993:659.

3. (a) Myers AG, Zheng B. J Am Chem Soc 1996;118:4492. (b) Myers AG, Zheng B. Tetrahedron Lett 1996;37:4841. (c) Myers AG, Movassaghi M, Zheng B. J Am Chem Soc 1997;119:8572.

4. (a) Myers AG, Kukkola PJ. J Am Chem Soc 1990;112:8208. (b) Myers AG, Movassaghi M. J Am Chem Soc 1998;120:8891.

5. Sammis GM, Flamme EM, Xie H, Ho DM, Sorensen EJ. J Am Chem Soc 2005;127:8612. [PubMed: 15954764]

6. See also: Wood JL, Porco JA Jr, Taunton J, Lee AY, Clardy J, Schreiber SL. J Am Chem Soc 1992;114:5898.

7. For reviews of allylic strain directed reactions see: Hoffman RW. Chem Rev 1989;89:1841.Hoveyda AH, Evans DA, Fu G. C Chem Rev 1993;93:1307.

8. Kobayashi J, Sato Ishibashi M. J Org Chem 1993;58:2645.

9. D’Auria MV, Gomez-Paloma L, Minale L, Zampella A, Verbist JF, Roussakis C, Dibitus C, Patissou J. Tetrahedron 1994;50:4829.

10. Wasserman HH, Van Verth JE, McCaustland DJ, Borowitz IJ, Kamber B. J Am Chem Soc 1967;89:1535. [PubMed: 6041359]

11. Tachibana K, Scheuer PJ, Tsukitani Y, Kikuchi H, Van Engen D, Clardy J, Gopichand Y, Schmitz FJ. J Am Chem Soc 1981;103:2469.

12. Kuramoto M, Tong C, Yamada K, Chiba T, Hayashi Y, Uemura D. Tetrahedron Lett 1996;37:3867.

13. Chou T, Kuramoto M, Otani Y, Shikano M, Yazawa K, Uemura D. Tetrahedron Lett 1996;37:3871.

14. Goma, Yuki; Matsumoto, Yoichi. Reduction of optically active imines. Jpn. Kokai Tokkyo Koho 2001064244: 2001.

15. Iida H, Yamazaki N, Harada K, Shiono S. Bull Chem Soc Jap 1984;57:1040.Kibayashi C. J Chem Soc Chem Commun 1987:746.Fujita M, Hiyama T. J Org Chem 1988;53:5415.Williams DR, Osterhout MH, Reddy JP. Tetrahedron Lett 1993;34:3271.Uneyama K, Hao J, Amii H. Tetrahedron Lett 1998;39:4079.Shimizu M, Tsukamoto K, Matsutani T, Fujisawa T. Tetrahedron 1998;54:10265.Boukhris S, Souizi A. Tetrahedron Lett 1999;40:1669.Miyata O, Koizumi T, Asai H, Iba R, Naito T. Tetrahedron 2004;60:3893.

16. See Supporting Information.

17. Kabalka GW, Yang DTC, Baker JD Jr. J Org Chem 1976;41:574.

18. The 1,4-cis configuration of 2 a was confirmed by its conversion to the known cis-2-methyl-5hexanolide (see Supporting Information).

19. The $e r$ of the Weinreb amide leading to $2 \mathrm{~d}$ was $3: 1$.

Org Lett. Author manuscript; available in PMC 2009 January 5. 
20. See, for example: Cywin CL, Kallmerten J. Tetrahedron Lett 1993;34:1103.Kim D, Shin KJ, Kim IY, Park SW. Tetrahedron Lett 1994;35:7957.For reviews, see: HiersemannMNubbemeyerUThe Claisen Rearrangement: Methods and ApplicationsWiley-VCHWeinheim2007

21. For a review see Nakai T, Mikami K. Chem Rev 1986;86:885.

22. Ibuka T, Tanaka M, Nishii S, Yamamoto Y. J Am Chem Soc 1989;111:4864.Ibuka T, Nakai K, Habashita H, Bessho K, Fujii N. Tetrahedron 1993;49:9479. 


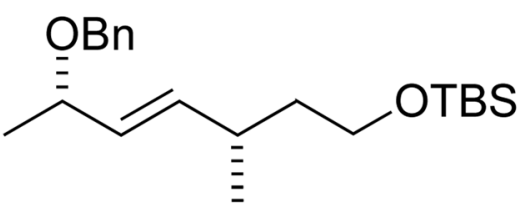

2b $85 \%$<smiles>C=C[C@H](C)/C=C/[C@H](C)OCc1ccccc1</smiles>

2c $81 \%$

igure

Reductive Transposition Products $\mathbf{2 b - \mathbf { f }}$<smiles></smiles>

2d $88 \%$
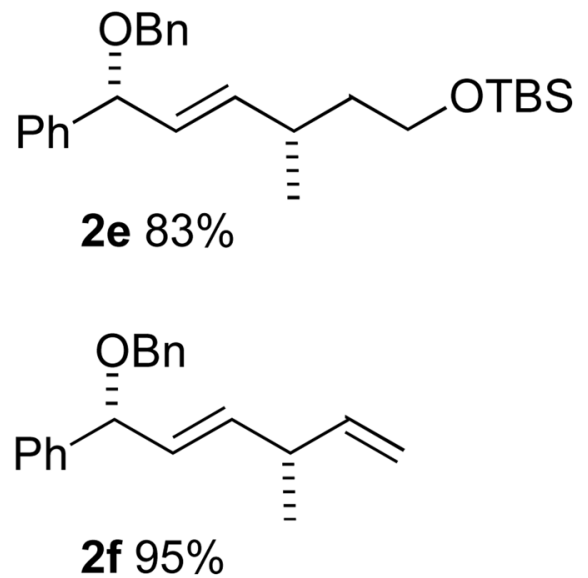

Org Lett. Author manuscript; available in PMC 2009 January 5. 

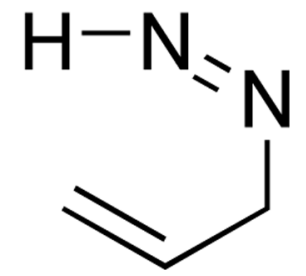

Scheme 1.

The Allylic Diazene Rearrangement

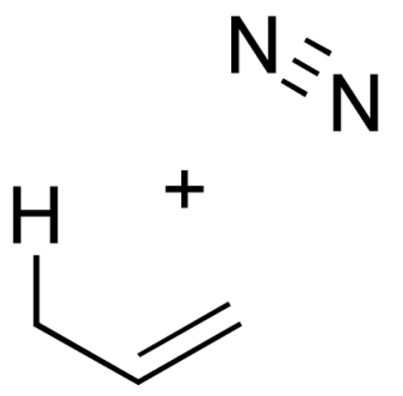


<smiles>[R]C([R20])=CC(=NNS(=O)(=O)Br)C([R20])O[CH]</smiles><smiles>[R2]OC([R20])C(C=C([R])[R])N=N</smiles><smiles>[R][CH]C</smiles><smiles>C#C</smiles><smiles>[R3]C([R])=C[C@@H](/N=N\[H])C([R])[R20]</smiles>

Scheme 2.

Acyclic Diastereoselective Reductive Transposition

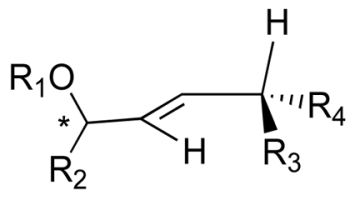




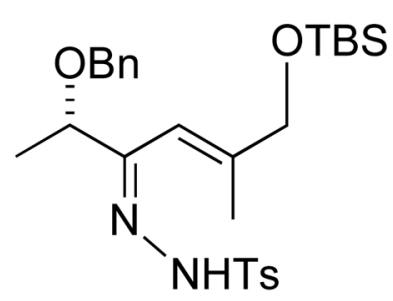

$1 a$
1. $\mathrm{HB}(\mathrm{OR})_{2}$ silica gel $\mathrm{CHCl}_{3}$ $-42{ }^{\circ} \mathrm{C}$ to rt

2. $\mathrm{NaOAc}$ reflux, $6 \mathrm{~h}$

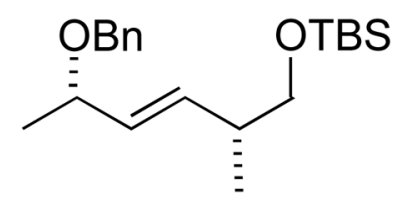

2a $92 \%, \geq 20: 1 d r$

Scheme 3.

Reductive Transposition of Hydrazone 1a 
<smiles>[3H]N/N=C(\C=C(\C)C(C)(C)[OH2+])C(OCc1ccccc1)c1ccccc1</smiles>

$\lg \mathrm{n}=1$

$1 \mathrm{~h} n=2$
1. $\mathrm{HB}(\mathrm{OR})_{2}$

silica gel

$\mathrm{CHCl}_{3}$

$-42{ }^{\circ} \mathrm{C}$ to rt

\section{2. $\mathrm{NaOAc}$} reflux, $6 \mathrm{~h}$

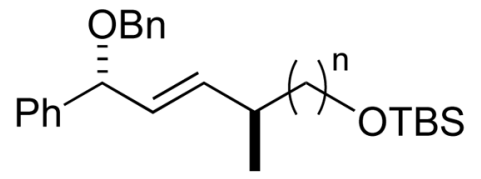

2g, $85 \%$

2h, $80 \%$

Scheme 4.

Preparation of 1,4-anti Adducts 2g,h. 